\title{
The Common Reed (Phragmites australis) as a Source of Roughage in Ruminant Nutrition
}

\author{
M. BARAN ${ }^{1}$, Z. VÁRADYOVÁ ${ }^{1}$, S. KRÁČMAR ${ }^{2}$, J. HEDBÁVNÝ
}

${ }^{1}$ Institute of Animal Physiology, Slovak Academy of Sciences, Košice, Slovak Republic ${ }^{2}$ Mendel University of Agriculture and Forestry, Brno, Czech Republic

Received July 1, 2002

Accepted November 18, 2002

\section{Abstract}

Baran M., Z. Váradyová, S. Kráčmar, J. Hedbávný: The Common Reed (Phragmites australis) as a Source of Roughage in Ruminant Nutrition. Acta Vet. Brno 2002, 71: 445- 449.

The use of common reed (Phragmites australis) as a potential source of roughage in ruminant nutrition was investigated in vitro. The fermentation parameters (total gas production, methane, total and individual volatile fatty acids) of Phragmites australis, meadow hay, wheat straw, barley, amorphous cellulose and glucose were compared. Fermentation was carried out in $120 \mathrm{ml}$ serum bottles and measurements were made by means of the pressure transducer technique. Amino acids, chemical and mineral composition of Phragmites australis were determined. Phragmites australis had a relatively high content of magnesium $\left(2.65 \mathrm{~g} \cdot \mathrm{kg}^{-1}\right)$, potassium $\left(10.9 \mathrm{~g} \cdot \mathrm{kg}^{-1}\right)$ and manganese $\left(97.0 \mathrm{mg} \cdot \mathrm{kg}^{-1}\right)$. Phragmites australis dry matter digestibility ranged within the dry matter digestibility of meadow hay $(50.2 \%)$ and wheat straw $(36.6 \%)$ and achieved $41.8 \%$. Methane production of Phragmites australis was significantly higher compared to that of wheat straw and meadow hay. The total gas production of barley, amorphous cellulose and glucose was significantly higher $(P<0.001)$ compared to Phragmites australis. Phragmites australis gave a high acetate/propionate ratio (4.4) compared to other substrates, as well. Our results of the in vitro experiment thus indicate a potential use of Phragmites australis as a new source of roughage with favourable content mainly of nitrogen, $\mathrm{K}$ and $\mathrm{Mn}$. However, further research is needed to obtain information from in vivo experiments.

Phragmites australis, rumen fermentation, methane, volatile fatty acids, in vitro

Phragmites australis is a large perennial rhizomatous grass, or reed especially common in alkaline and brackish environments (Haslam 1972). Phragmites australis used in the present experiment is a tall plant $(2.0-4.0 \mathrm{~m})$ found in freshwater wetlands, and it is interesting as a source of cellulose and energy. Cattle and horses graze this grass during winter as a protein source, but common reed is unpalatable after maturity. Young shoots are used as a vegetable. The stalks exude a manna-like gum that may be eaten. The rhizomes and roots also serve as emergency food. Phragmites australis is an efficient colonizer of disturbed environments because it seeds profusely and spreads vegetatively by a vigorous system of rhizomes and stolons (Hara et al. 1993; Marks et al. 1994). Phragmites australis is typically the dominant species on the areas that it occupies. The aggressive nature of Phragmites australis is a direct reflection of the adaptive features of its life cycle. In the last decade, Phragmites australis has been expanded on the land with the highest content of $\mathrm{MgO}$ near the factory Slovmag (Lubeník Slovakia). The objective of the present in vitro study was to determine the fermentation parameters of Phragmites australis and explore its possible use in ruminant nutrition.

\section{Materials and Methods}

The ruminal fluid inoculum used in the present experiment was obtained from the two rumen fistulated Merino sheep fed meadow hay and ground barley at a ratio of 80:20. The samples of rumen fluid were taken $3 \mathrm{~h}$ after the morning feeding, transferred to the laboratory in a water bath preheated to $39 \pm 0.5^{\circ} \mathrm{C}$, squeezed through four layers

Address for correspondence:

MVDr. Miroslav Baran, DrSc

Institute of Animal Physiology SAS

Institute of Animal Physiology SAS
Šoltésovej 4-6, 040 Košice

Soltevavevej 4-6, Republic
Phone: +421557287841

Fax: +4215572878 42

http://www.vfu.cz/acta-vet/actavet.htm 
of gauze and purged with $\mathrm{CO}_{2}$. The rumen fluid was mixed with McDougall's buffer (McDougall 1948) at a ratio of $1: 2$ and pumped by an automatic pump at $35 \mathrm{ml}$ doses into each of preheated fermentation bottles ( $120 \mathrm{ml}$ serum bottles) containing substrates and incubated in the incubator for $72 \mathrm{~h}$ at $39 \pm 0.5^{\circ} \mathrm{C}$.

The fermentation bottles contained $0.25 \mathrm{~g}$ of substrate. The following six substrates were used: Phragmites australis, meadow hay, wheat straw, barley, amorphous cellulose and glucose. Phragmites australis came from Lubenik region (Slovakia). Dry stalks and leaves from Phragmites were used. The fibrous material (meadow hay, wheat straw and Phragmites australis) was ground and afterwards passed through three successive sieves with a mesh size of $0.15-0.4 \mathrm{~mm}$. Six replicates were used for all experimental groups (rumen inoculum, substrate) and six replicate bottles were used for the control (rumen inoculum, no substrate).

The volume of released accumulated gas was measured after $72 \mathrm{~h}$ by the mechanical pressure transducer technique developed by Várady ová et al. (1998). Gases from each fermentation bottle were collected in a $2 \mathrm{ml}$ glass syringe at the end of the incubation and immediately analyzed for methane concentration by gas chromatography. The concentration of volatile fatty acid (VFA) in the medium was determined after $72 \mathrm{~h}$ by gas chromatography (Cottyn and Boucque 1968) using crotonic acid as the internal standard and a Perkin-Elmer 8500 gas chromatograph. Hydrogen recoveries were calculated according to Demeyer and V an Nevel (1975). Dry matter digestibility (DM digestibility) was estimated from the difference of the substrate weight before and after $72 \mathrm{~h}$ incubation (Mellenberger et al. 1970). Phragmites was analyzed for dry matter (DM; $24 \mathrm{~h}$ at $\left.103^{\circ} \mathrm{C}\right)$ and ash $\left(4 \mathrm{~h}\right.$ at $550^{\circ} \mathrm{C}$ ). Nitrogen content was determined using the Kjeldahl procedure (AOAC 1990) and Kjeltec Auto 1031 Analyzer (Tecator). Crude fat was determined using the Twieselman apparatus. A single amino acid analysis was carried out as described by Van Vuuren et al. (1992) using the AAA 400 apparatus (Ingos Praha). Concentrations of minerals were determined using an apparatus Spectral AA 30 Varian.

The means of the individual parameters were compared using the Student-Newman-Keuls test (Graphpad InStat, GraphPad Software, Inc. San Diego, USA).

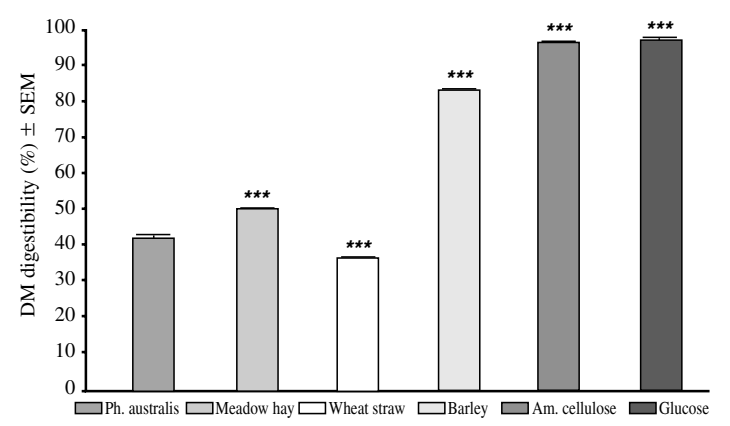

Fig. 1. DM digestibility of Phragmites australis, meadow hay, wheat straw, barley, amorphous cellulose and glucose incubated with rumen inoculum in vitro, for $72 \mathrm{~h}$. Significance: $* P<0.05$; *** $P<0.001$.

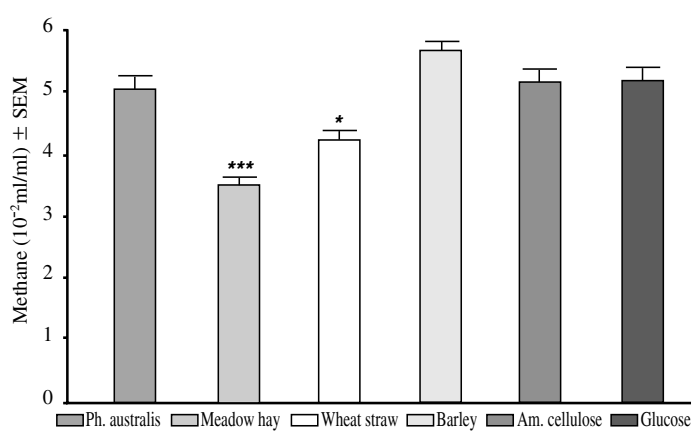

Fig. 2. Methane production of Phragmites australis, meadow hay, wheat straw, barley, amorphous cellulose and glucose incubated with rumen inoculum in vitro, for $72 \mathrm{~h}$. Significance: $* P<0.05 ; * * * P<0.001$.

\section{Results}

In comparison to the Phragmites australis, the DM digestibility of all substrates (meadow hay, barley, amorphous cellulose and glucose) was higher $(P<0.001)$ except for wheat straw, where the DM digestibility was lower (Fig. 1). As compared to Phragmites australis, significantly lower values $(P<0.001 ; P<0.05)$ of methane production were obtained for meadow hay and wheat straw (Fig. 2). Total gas production of barley, amorphous cellulose and glucose in our study was higher $(P<0.001)$ compared to the Phragmites (Table 2). Total VFA production was significantly lower in meadow hay, wheat straw $(P<0.001)$ and in barley $(P<0.01)$, however, it was higher in amorphous cellulose $(P<0.001)$. Acetate production was lower in barley, amorphous cellulose and glucose $(P<0.001)$ compared to Phragmites. Propionate was higher in all substrates $(P<0.001)$. As compared to Phragmites, iso-valerate and nvalerate were significantly lower $(P<$ $0.001)$ in meadow hay, wheat straw, amorphous cellulose and glucose. Iso- 
Table 1

Amino acids, chemical and mineral composition of Phragmites australis

\begin{tabular}{|c|c|c|c|}
\hline \multicolumn{2}{|c|}{ Amino acids } & \multicolumn{2}{|c|}{ Chemical composition } \\
\hline $\operatorname{Thr}\left(\mathrm{g} \cdot \mathrm{kg}^{-1}\right)$ & 4.393 & Dry matter $(\%)$ & 93.8 \\
\hline $\operatorname{Val}\left(\mathrm{g} \cdot \mathrm{kg}^{-1}\right)$ & 3.604 & $\mathrm{~N}$-substances $\left(\mathrm{g} \cdot \mathrm{kg}^{-1}\right)$ & 120.6 \\
\hline Ile $\left(\mathrm{g} \cdot \mathrm{kg}^{-1}\right)$ & 3.158 & Crude fat $\left(\mathrm{g} \cdot \mathrm{kg}^{-1}\right)$ & 18.2 \\
\hline Leu $\left(\mathrm{g} \cdot \mathrm{kg}^{-1}\right)$ & 6.042 & Crude fibre $\left(\mathrm{g} \cdot \mathrm{kg}^{-1}\right)$ & 278.3 \\
\hline Tyr $\left(\mathrm{g} \cdot \mathrm{kg}^{-1}\right)$ & 4.962 & $\operatorname{Ash}\left(\mathrm{g} \cdot \mathrm{kg}^{-1}\right)$ & 67.3 \\
\hline Phe $\left(\mathrm{g} \cdot \mathrm{kg}^{-1}\right)$ & 4.995 & $\mathrm{~N}$-free substances $\left(\mathrm{g} \cdot \mathrm{kg}^{-1}\right)$ & 453.4 \\
\hline His $\left(\mathrm{g} \cdot \mathrm{kg}^{-1}\right)$ & 2.200 & Organic matter $\left(\mathrm{g} \cdot \mathrm{kg}^{-1}\right)$ & 870.5 \\
\hline Lys $\left(\mathrm{g} \cdot \mathrm{kg}^{-1}\right)$ & 5.082 & Mineral composition: & \\
\hline $\operatorname{Arg}\left(\mathrm{g} \cdot \mathrm{kg}^{-1}\right)$ & 7.247 & $\mathrm{Ca}\left(\mathrm{g} \cdot \mathrm{kg}^{-1}\right)$ & 2.660 \\
\hline $\operatorname{Met}\left(\mathrm{g} \cdot \mathrm{kg}^{-1}\right)$ & 0.378 & $\mathrm{Mg}\left(\mathrm{g} \cdot \mathrm{kg}^{-1}\right)$ & 2.649 \\
\hline $\operatorname{Asp}\left(\mathrm{g} \cdot \mathrm{kg}^{-1}\right)$ & 9.819 & $\mathrm{~K}\left(\mathrm{~g} \cdot \mathrm{kg}^{-1}\right)$ & 10.899 \\
\hline $\operatorname{Ser}\left(\mathrm{g} \cdot \mathrm{kg}^{-1}\right)$ & 4.330 & $\mathrm{Na}\left(\mathrm{g} \cdot \mathrm{kg}^{-1}\right)$ & 0.534 \\
\hline Glu $\left(\mathrm{g} \cdot \mathrm{kg}^{-1}\right)$ & 9.376 & $\mathrm{P}\left(\mathrm{g} \cdot \mathrm{kg}^{-1}\right)$ & 1.575 \\
\hline Pro $\left(\mathrm{g} \cdot \mathrm{kg}^{-1}\right)$ & 7.081 & $\mathrm{Fe}\left(\mathrm{mg} \cdot \mathrm{kg}^{-1}\right)$ & 58.750 \\
\hline Gly $\left(\mathrm{g} \cdot \mathrm{kg}^{-1}\right)$ & 4.307 & $\operatorname{Mn}\left(\mathrm{mg} \cdot \mathrm{kg}^{-1}\right)$ & 96.964 \\
\hline Ala $\left(\mathrm{g} \cdot \mathrm{kg}^{-1}\right)$ & 6.981 & $\mathrm{Zn}\left(\mathrm{mg} \cdot \mathrm{kg}^{-1}\right)$ & 26.964 \\
\hline Cys $\left(\mathrm{g} \cdot \mathrm{kg}^{-1}\right)$ & 0.199 & $\mathrm{Cu}\left(\mathrm{mg} \cdot \mathrm{kg}^{-1}\right)$ & 8.452 \\
\hline
\end{tabular}

butyrate and n-butyrate of the amorphous cellulose were lower $(P<0.001)$. N-butyrate of barley and glucose and also n-caproate of barley was higher $(P<0.001)$ compared to Phragmites australis. The A/P ratio for all the substrates used was significantly lower compared to Phragmites. Hydrogen recovery in barley, amorphous cellulose and glucose was significantly higher, however, in meadow hay was lower $(P<0.05)$ compared to Phragmites.

\section{Discussion}

The data on chemical and mineral composition and also composition of amino acids of Phragmites used in our experiment are summarized in Table 1. These data indicate that

Table 2

Production of total gas, volatile fatty acids (VFA), acetate/propionate ratio (A/P) and 2-H recovery of substrates incubated for $72 \mathrm{~h}$.

\begin{tabular}{|c|c|c|c|c|c|c|c|c|}
\hline & Control & Ph.australis & Meadow hay & Wheat straw & Barley & Am. cellulose & Glucose & SEM \\
\hline Total gas (ml) & 26.8 & 45.9 & 50.0 & 46.7 & $61.7 * * *$ & $73.3 * * *$ & $72.6^{* * *}$ & 1.2 \\
\hline Total VFA (mM) & 52.6 & 59.4 & $39.7 * * *$ & $33.2 * * *$ & $51.0 * *$ & $77.3^{* * * *}$ & 61.0 & 1.3 \\
\hline Acetate $(\mathrm{mol} \%)$ & 68.2 & 68.1 & 67.4 & 68.0 & $60.5 * * *$ & $60.3 * * *$ & $60.0 * * *$ & 0.3 \\
\hline Propionate (mol\%) & 15.4 & 16.3 & $18.4^{* * *}$ & $19.2^{* * *} *$ & $20.0 * * *$ & $28.2 * * *$ & $21.6^{* * *}$ & 0.2 \\
\hline Iso-butyrate $(\mathrm{mol} \%)$ & 1.2 & 1.2 & 1.0 & 1.0 & 1.2 & $0.9 * * *$ & 1.0 & 0.04 \\
\hline N-butyrate (mol\%) & 10.6 & 10.2 & 9.9 & 9.6 & $13.9 * * *$ & $7.7 * * *$ & $13.8 * * *$ & 0.2 \\
\hline Iso-valerate (mol\%) & 1.9 & 1.8 & $1.6^{* *}$ & $1.6^{* *}$ & 1.8 & $1.2 * * *$ & $1.5^{* * *}$ & 0.1 \\
\hline $\mathrm{N}$-valerate $(\mathrm{mol} \%)$ & 2.5 & 2.3 & $1.7 * * *$ & $1.9 * * *$ & 2.1 & $1.7 * * *$ & $1.8 * * *$ & 0.04 \\
\hline N-caproate (mol\%) & 0.3 & 0.2 & 0.2 & 0.2 & $0.5^{* * *}$ & 0.1 & $0.4^{*}$ & 0.1 \\
\hline $\mathrm{A} / \mathrm{P}$ & 4.4 & 4.2 & $3.7 * * *$ & $3.6 * * *$ & $3.0 * * *$ & $2.1 * * *$ & $2.8^{* * *}$ & 0.1 \\
\hline $2 \mathrm{H}$-recovery (\%) & 38.7 & 44.0 & $39.2 *$ & 41.5 & $51.6^{* * * *}$ & $53.7 * * *$ & $48.9^{*}$ & 0.6 \\
\hline
\end{tabular}

$* P<0.05$; ** $P<0.01$; *** $P<0.001$ different from Phragmites australis; $(\mathrm{n}=6)$; SEM = standard error of the mean 
Phragmites is a good source of nitrogen substances and also of potassium, and especially manganese. The amount of manganese $\left(97 \mathrm{mg} \cdot \mathrm{kg}^{-1}\right)$ was higher than in other roughage. For comparison the Mn content of meadow hay of the medium quality is $35.5 \mathrm{mg} \cdot \mathrm{kg}^{-1} \mathrm{DM}$ (Kováč et al. 1987). Sviatko (1991) reported the Mn content in meadow hay of 94.9 $\mathrm{mg} \cdot \mathrm{kg}^{-1} \mathrm{DM}$. The availability of limiting nutrients, mainly nitrogen and, to some extent manganese and potassium, is therefore of special importance for common reed. We previously tested the fermentation parameters of meadow hay, wheat straw, beech sawdust, barley straw, maize stalk, sugarcane bagasse. The DM digestibility in the fermentation process with the same inoculum ranged from $37.5 \%$ to $55.8 \%$ for wheat straw and meadow hay, respectively (Zeleňák et al. 1987; Váradyová et al. 2000). The DM digestibility of Phragmites australis in the study ranged within the DM digestibility of meadow hay $(50.2 \%)$ and wheat straw $(36.6 \%)$ and achieved $41.8 \%$. However, no significant differences were observed in the production of total gas in Phragmites, meadow hay and wheat straw. According to some authors (France et al. 1993; Getachew at al. 1998) gas production is a more sensitive parameter of fermentation than DM digestibility. This suggests that Phragmites australis may be compared to the roughage with lower DM digestibility such as wheat straw. The fibrous materials in this study yielded high acetate/propionate ratios. This was due to a relatively low propionate production as described in literature (Czerkawski 1986; Durand et al. 1988; Zeleňák 1991).

It is concluded that in many ecosystems common reed (Phragmites australis) serves as an excellent stabilizer of soil and acts as an efficient nutrient sink through its accumulation of large quantities of persistent biomass. Our results indicate a possibility of using Phragmites australis (especially as a source of nitrogen, $\mathrm{K}$ and $\mathrm{Mn}$ ) as a partial replacement of roughage for ruminants. The results of the present in vitro experiment will provide a basis for in vivo experiments with the final goal to use this new roughage as a partial replacement in agricultural practice. Further in vivo studies are expected to provide data on biochemistry, energy and ecology.

\section{Trst' obecná (Phragmites australis) ako potenciálny zdroj objemového krmiva vo výžive prežúvavcov}

Sledovali sme možnost’ využitia trsti obecnej (Phragmites australis) ako potenciálneho zdroja náhrady objemového krmiva vo výžive prežúvavcov. $\mathrm{V}$ podmienkach in vitro boli porovnávané fermentačné parametre (produkcia plynov, metánu a unikavých mastných kyselín) trsti obecnej s inými substrátmi (lúčne seno, pšeničná slama, jačmeň, amorfná celulóza a glukóza). Fermentácia prebiehala v $120 \mathrm{ml}$ flašiach na sérum a merania plynu sa uskutočnili mechanickým tlakovým manometrom. Pri trsti obecnej boli stanovené základné živiny, minerálne látky a aminokyseliny. $\mathrm{Z}$ chemického hladiska bola trst' obecná bohatým zdrojom dusíkatých látok. Z hladiska minerálneho zloženia bola bohatá na draslík $\left(10,9 \mathrm{gkg}^{-1}\right)$ a na mangán $\left(97,0 \mathrm{mg} \cdot \mathrm{kg}^{-1}\right)$. Namerané hodnoty strávitelnosti trsti obecnej $(41,8 \%)$ boli medzi strávitelnostou lúčneho sena $(50,2 \%)$ a pšeničnej slamy $(36,6 \%)$. Metánová produkcia pri trsti obecnej bola vyššia $v$ porovnaní s lúčnym senom a pšeničnou slamou. Produkcia celkových plynov bola vyššia pri jačmeni, amorfnej celulóze a glukóze $(P<0,001) \mathrm{v}$ porovnaní s trstou obecnou. Bol zaznamenaný vysoký pomer acetát / propionát $(4,4)$ pre trst obecnú v porovnaní s ostatnými substrátmi. Dosiahnuté výsledky poukazujú na možnosṫ náhrady suchých objemových krmív trstou obecnou, ktorá je dobrým zdrojom dusíka, draslíka a mangánu, avšak jej praktické využitie vyžaduje dalšie pokusy hlavne v in vivo podmienkach.

Acknowledgements

This study was supported by the Grant Agency for Science (VEGA) of the Slovak Academy of Sciences (Grants No. 2/1165/21 and No. 2/7029/21). 


\section{References}

AOAC 1990: Official Methods of Analysis. 15th ed. Association of Official Analytical chemists, Arlington, VA. COTTYN, BG, BOUCQUE, CV 1968: Rapid method for the gas chromatographic determination of volatile fatty acids in rumen fluid. J Agric Food Chem 16:105-107

CZERKAWSKI, JW 1986: An introduction to rumen studies. Pergamon Press, New York, 342 p.

DEMEYER DI, VAN NEVEL, CJ 1975: Methanogenesis, an integrated part of carbohydrate fermentation, and its control. In: Proceedings of the Fourth International Symposium on Rumen Physiology. University of New England Publication Unit, Armidale, Australia, pp. 366-382

DURAND, M, DUMAY, C, BEAUMATIN, P, MOREL, MT 1988: Use of the rumen simulation technique (Rusitec) to compare microbial digestion of various by-products. Anim Feed Sci Technol 21:197-204

FRANCE, J, DHANOA, MS, THEODOROU, MK, LISTER, SJ, DAVIES, DR, ISAC, D 1993: A model to interpret gas accumulation profiles associated with in vitro degradation of ruminant feeds. J Theor Biol 163: 99111

GETACHEW G, BLÜMMEL, M, MAKKAR, HPS, BECKER, K 1998: In vitro gas measuring techniques for assessment of nutritional quality of feeds: a review. Anim Feed Sci Technol 72: 261-281

HASLAM, SM 1972: Phragmites communis Trin. Biological flora British Isles. J Ecol 60: 585-610

HARA, T, VAN DER TOORN, J, MOOK, JH 1993: Growth dynamics and size structure of shoots of Phragmites australis, a clonal plant. J Ecol 81: 47-60

KOVÁČ, M 1987: Biologická a ekonomická optimalizácia výživy hospodárskych zvierat. Príroda, Bratislava, $422 \mathrm{p}$.

MARKS, M, LAPIN, B, RANDALL J 1994: Phragmites australis (P. communis): threats, management and monitoring. Natural Areas J 14: 285-294

McDOUGALL, EJ 1948: Studies on ruminant saliva. 1. The composition and output of sheep's saliva. Biochem J 43:99-109

MELLENBERGER, RW, SATTER, LD, MILLET, MA, BAKER, AJ 1970: An in vitro technique for estimating digestibility of treated and untreated wood. J Anim Sci 30: 1005-1011

SVIATKO, P 1991: Trace element nutrition in ruminants. In: KOPPEL, J, BARAN, M (Eds): Animal physiology. Institute of Animal Physiology, Košice, pp. 147-161

VAN VUUREN, AM, KROL-KRAMER, F, VAN DER LEE, RA, CORBIJN, H 1992: Protein digestion and intestinal amino acids in dairy cows fed fresh Lolium perenne with different nitrogen contents. J Dairy Sci 75: 2215-2225

VÁRADYOVÁ, Z, ZELEŇÁK, I, SIROKA, P 1998: The comparison of in vitro fermentation kinetics estimated by three different methods. Arch Anim Nutr 51: 319-326

VÁRADYOVÁ, Z, ZELENAÁK, I, SIROKA, P 2000: In vitro study of the rumen and hindgut fermentation of fibrous materials (meadow hay, beech sawdust wheat straw) in sheep. Anim Feed Sci Technol 83: 127-138

ZELEŇÁK, I 1991: Secondary wood-based raw materials in nutrition of farm animals. Veda, Bratislava, 142 p.

ZELEŇÁ, I, JALČ, D, BUČKO, J, KRIVÁŇOVÁ, M, SIROKA, P 1987: Digestibility of lignocellulose materials treated by a defibration technique. Vet. Med. Praha 32: 209-217 